\title{
PERBANDINGAN APLIKASI TERAPI AKUPUNKTUR DENGAN SUSU FERMENTASI KEFIR UNTUK MENGHAMBAT PROSES PENUAAN DINI DI KOTA SURAKARTA
}

\author{
Sri Yatmihatun ${ }^{1)}$, Estuningsih ${ }^{2)}$ \\ 1,2 Politeknik Kemenkes Surakarta \\ e-mail:asriyatmi79@yahoo.com
}

\begin{abstract}
ABSTRAK
Penuaan atau aging merupakan perubahan manusia yang diakibatkan oleh faktor usia, psikologi, dan sosial. Penuaan juga dipengaruhi oleh faktor reactitive oxygen species (ROS) yang dihasilkan dalam sel. Tindakan akupunktur pada titik Zusanli (ST36) untuk anti aging mempunyai efek dalam melawan penuaan dengan meningkatnya aktivitas serum SOD dan penurunan serum Malondialdehyde (MDA). Kefir merupakan minuman susu fermentasi oleh mikroba atau bakteri asam laktat (Lactobacillus acidophilus, L. kefir, L. kerfigranum, L. parakefir) sehingga dikenal sebagai minuman probiotik karena mengandung mikroba yang baik untuk sistem pencernaan sehingga diketahui dapat berperan sebagai mencegah penuaan (aging). Tujuan penelitian untuk mengetahui perbedaan antara antara aplikasi terapi akupunktur dengan susu fermentasi kefir untuk menghambat proses penuaan dini di Kota Surakarta. Metode penelitian adalah Quasy eksperimental dengan pendekatan Randomized Controlled Trial. Hasil penelitian menunjukkan skor anti oksidan pada kelompok sebelum terapi akupunktur sebesar 22.823,53 dan kelompok pemberian susu fermentasi kefir sebesar 20.352,94, dan gabungan kelompok pemberian terapi akupunktur dan pemberian susu fermentasi kefir sebesar 23.411,76. Skor anti oksidan pada kelompok setelah terapi akupunktur 18.176,47 kelompok pemberian susu fermentasi kefir, 17.764,70, dan gabungan kelompok pemberian terapi akupunktur dan pemeberian susu fermentasi kefir 19.294,12. Kesimpulan tidak ada perbedaan antara ketiga perlakuan yaitu pemberian terapi akupuntur; susu fermentasi kefir maupun kombinasi pemberian terapi akupuntur dan susu fermentasi kefir untuk menghambat proses penuaan dini di Kota Surakarta namun perpaduan akupunktur dan pemberian kefir mempunyai hasil yang lebih bagus. Manfaat dari penelitian yaitu aplikasi akupunktur dan kefir minuman fermentasi dapat dijadikan referensi untuk inovasi sebagai terapi alternatif pada kasus penuaan dini.
\end{abstract}

Kata kunci : akupunktur, kefir, penuaan dini, terapi

\section{ABSTRACT}

Aging is a human change caused by age, psychology, and social factors. Aging is also influenced by the Reactitive Oxygen Species (ROS) factors produced in cells. The acupuncture action at the Zusanli point (36) for anti-aging results has an effect against aging with increasing serum SOD activity and decreasing serum Malondialdehyde (MDA). Kefir is a fermented milk drink by microbes or lactic acid bacteria (Lactobacillus acidophilus, L. kefir, L. kerfigranum, L. parakefir) so it is known as a probiotic drink because it contains microbes that are good for the digestive system so that it is known to play a role as preventing aging (aging). The purpose of this study was to determine the difference between the application of acupuncture therapy with kefir fermented milk to inhibit the process of premature aging in the city of Surakarta. The research method is an experimental Quasy with a Randomized Controlled Trial approach. The results showed the antioxidant score in the group before acupuncture therapy was 22,823.53 and the group giving kefir fermentation milk was 20,352.94, and the combined group giving acupuncture therapy and giving kefir fermentation milk was 23,411.76. Anti-oxidant score in the group after acupuncture therapy 18,176.47 group giving kefir fermentation milk, 17,764.70, and combined group giving acupuncture therapy and giving kefir fermentation milk 19,294.12. Conclusion there is no difference between the three treatments, namely the provision of acupuncture therapy; Kefir fermented milk and a combination of acupuncture therapy and kefir fermented milk to inhibit the process of premature aging in the city of Surakarta. The benefits of the research are the application of acupuncture and 
fermented beverage kefir can be used as a reference for innovation as an alternative therapy in cases of premature aging.

Keywords: acupuncture, kefir, early aging, therapy

\section{PENDAHULUAN}

Penuaan atau aging merupakan perubahan manusia yang diakibatkan oleh faktor usia, psikologi, dan sosial. Pada umumnya aging diartikan sebagai perubahan fisik manusia. Perubahan fisik dapat dihambat dengan salah satunya menggunakan anti aging seperti obat atau kosmetik (Maria, 2007). Penuaan juga dipengaruhi oleh faktor reactitive oxygen species (ROS)yang dihasilkan dalam sel. ROS adalah produk sampingan dari respirasi aerobic yang terlibat dalam beberapa modifikasi reaksi seluler seperti paparan logam berat, radiasi pengion maupun zat anti oksidan. Secara normal ROS dapat dihilangkan oleh adanya antioksidan endogen seperti superoksida dismutase (SOD, katalase (CAT), glutathione peroksidase (GPx) dan glutathione reduktase (GR) (Nur et.al, 2017)

Salah satu komponen di dalam sel manusia, yaitu mitochondria SOD sebagai antioxidant (kang yang ji) yang mampu menyapu bersih radikal bebas di dalam tubuh. Maka zat SOD memegang peranan penting dalam kesehatan manusia dan umur panjang. Sayur mayur dan buah-buahan segar, bijibijian mengandung antioksidant yang kuat, seperti beta -carotine, Vitamin $\mathrm{A}, \mathrm{C}$, dan $\mathrm{E}$. Berhubung manusia lansia produksi SOD makin berkurang, maka perlu makan banyak sayur-sayuran dan buah-buahan segar untuk kompensasi zat antioksidant yang makin berkurang. Vitamin A, C, dan E adalah antioksidant yang paling kuat untuk menetralisir radikal bebas di dalam tubuh. Zat mineral Copper $(\mathrm{Cu})$, Selenium (Se), Seng $(\mathrm{Zn})$, besi $(\mathrm{Fe})$ adalah antioksidan yang kuat.

Xei Yi-cong \& Tang Fang (2008) telah melakukan penelitian dengan melakukan tindakan akupunktur pada titik Zusanli (36) untuk anti aging dengan hasil mempunyai efek dalam melawan penuaan dengan meningkatnya aktivitas serum SOD dan adanya penurunan serum Malondialdehyde (MDA). Kadar MDA serum merupakan biomarker adanya stress oksidatif. Peningkatan stress oksidatif menyebabkan kerusakan jaringan dan hemolysis. Selain itu akupunktur bisa menjadi intervensi potensial untuk memperlambat kejadian molekuler dengan penuaan pada mamalia (Ding et al. (2016).

Kefir merupakan minuman susu fermentasi oleh mikroba atau bakteri asam laktat (Lactobacillus acidophilus, L. kefir, L. kerfigranum, L. parakefir) sehingga dikenal sebagai minuman probiotik karena mengandung mikroba yang baik untuk sistem pencernaan sehingga bermanfaat antara lain menstimulasi sistem imun, menghambat tumor, antimikroba serta anti hiper kolesterolemia dan diketahui dapat berperan sebagai pencegah penuaan (aging) (Hidayat dkk, 2006).

Perumusan masalah dari hal tersebut adalah apakah terdapat perbedaan antara aplikasi terapi akupunktur dengan susu fermentasi kefir untuk menghambat proses penuaan dini di Kota Surakarta ?

Tujuan penelitian adalah untuk mengetahui perbedaan antara antara aplikasi terapi akupunktur dengan susu fermentasi kefir untuk menghambat proses penuaan dini di Kota Surakarta.

\section{METODE PENELITIAN}

Tempat penelitian di kota Surakarta pada bulan Maret hingga bulan Oktober 2019. Populasi dalam penelitian ini adalah wanita dan laki-kali yang berumur antara 20 sampai 55 tahun yang berada di wilayah Mojosongo Kota Surakarta. Pengambilan sampel pada penelitian menggunakan tehnik purposive sampling

Kriteria Inklusi dalam penelitian ini adalah Wanita yang berusia 20 sampai 55 tahun. Setelah diberi penjelasan / informed consent menandatangani persetujuan mengikuti prosedur penelitian sampai selesai. Kriteria Eksklusi adalah wanita yang tidak mengikuti peraturan sesuai dengan terapi akupunktur dan atau minum kerfir sesuai yang sudah dijadwalkan; dan wanita yang mempunyai penyakit kronis maupun akut saat pengambilan subyek penelitian. 
Jenis penelitian adalah Quasy eksperimental dengan pendekatan Randomized Controlled Trial. Penentuan kelompok subjek penelitian dilakukan secara random dengan membagi menjadi 3 kelompok masing kelompok terdiri dari 17 responden yaitu:

a. Kelompok yang mendapatkan terapi akupuktur dengan pemilihan titik Hegu (LI 4), Quchi (LI 11), Zusanli (ST 36) dan Dazhui (GB 14) selama 3 minggu dengan frekwensi 2 kali dalam seminggu.

b. Kelompok yang mendapatkan / minum susu fermentasi kerfir setiap hari selama 1 bulan.

c. Kelompok yang mendapatkan terapi akupunktur dengan pemilihan titik Hegu (LI 4), Quchi (LI 11), Zusanli (ST 36) dan Dazhui (GB 14) serta mendapatkan / minum susu fermentasi kerfir setiap hari selama 1 bulan.

Variabel bebas pada penelitian ini adalah pilihan titik akupunktur dan susu kerfir dengan skala pengukuran kategorikal. Variabel terikat pada penelitian ini adalah penuaan dini pada wanita usia 20-55 tahun dengan skala pengukuran kontinu.

Tahap pelaksanaan penelitian meliputi

a. Setelah subyek penelitian sudah terbagi menjadi 3 kelompok selanjutnya dibuat perlakuan untuk pemberian terapi akupunktur dan pemberian susu fermentasi kefir.

b. Selanjutnya akan melakukan pemeriksaan pengukurun pada kulit dengan menggunakan Pharmanex BioPhotonic Scanner S3 sebelum dilakukan terapi akupunktur atau pemberian susu fermentasi kefir.

c. Peneliti menyiapkan alat dan bahan untuk terapi diantaranya jarum filiform ukuran $0,20 \times 18 \mathrm{~mm}$ dan $0,25 \times 25 \mathrm{~mm}$, alkohol swab dan handscon dan juga susu fermentasi kerfir.

d. Pada perlakuan untuk kelompok pertama, peneliti memasang handscoen dan melakukan disinfeksi pada area titik yang akan dilakukan penusukan kemudian peneliti menusuk subyek penelitian menggunakan titik akupunktur sesuai dengan kelompok penentuan titiknya yaitu Hegu (LI 4)), Quchi (LI 11), Zusanli (ST 36) dan Dazhui (GB 14). e. Jarum akupunktur yang sudah tertancap akan dibiarkan selama 20 menit dan setiap 5 menit sekali, jarum akan diberikan manipulasi manual dengan disentil-sentil. Setelah terapi selesai, jarum akupunktur kemudian dicabut dan area titik bekas tusukan didisinfeksi kembali menggunakan alkohol swabs dilakukan 2 kali dalam seminggu.

f. Pada subyek penelitian pada kelompok pemberian susu akan diantar ke rumah atau mengambil ke tempat peneliti dan ditunggui sampai susu .

Setelah selesai melakukan pengambilan data maka akan melakukan pengukurun pada kulit dengan menggunakan Pharmanex BioPhotonic Scanner S3

Analisis data pada sampel yang berskala kontinu dideskripsikan dalam Mean, SD, minimum, maksimum. Pada sampel yang berskala kategorikal dideskripsikan dalam frekwensi dan persen. Perbedaan proses penuaan dini yang diukur dengan kadar anti oksidan antara ketiga modalitas terapi diuji secara statistikal dengan ANOVA dan Post Hock Test.

\section{HASIL DAN PEMBAHASAN}

Karakteristik subyek penelitian hanya dibedakan pada jenis kelamin dan usia dan dapat terlihat dalam tabel berikut:

Tabel 1. Distribusi Frekuensi subyek penelitian berdasarkan jenis kelamin

\begin{tabular}{lll}
\hline Jenis kelamin & Frekuensi & Persen \\
\hline Perempuan & 43 & 84,31 \\
Laki-laki & 8 & 15,69 \\
\hline Total & 51 & 100 \\
\hline
\end{tabular}

Berdasarkan tabel 1. diketahui jenis kelamin perempuan mendominasi pada responden yaitu $84,31 \%$ perempuan, dan $15 \%$ laki-laki.

Tabel 2. Distribusi Frekuensi berdasarkan tingkat usia

\begin{tabular}{lll}
\hline Usia & Frekuensi & Persen \\
\hline 20-30 tahun & 46 & 90,2 \\
30- 40 tahun & - & - \\
$>40$ tahun & 5 & 9,8 \\
\hline Total & 51 & 100 \\
\hline
\end{tabular}

Berdasarkan tabel 2. di atas, usia yang paling dominan adalah kurang dari 30 tahun yaitu 
90,2 \%, pemeriksaan anti oksidan ternyata tidak terpengaruh dengan usia.

Berdasarkan tabel 3. di atas menunjukkkan rata-rata subyek penelitian memiliki skor anti oksidan pada kelompok sebelum terapi akupunktur sebesar 22.823,53 dan kelompok pemberian susu fermentasi kefir sebesar
20.352,94, dan gabungan kelompok pemberian terapi akupunktur dan pemberian susu fermentasi kefir sebesar 23.411,76.

Tabel 3. Hasil pemeriksaan skor antioksidan sebelum dilakukan terapi akupunktur

\begin{tabular}{lccccc}
\hline & N & Min & Max & Mean & SD \\
\hline Akupunktur & 17 & 13.000 & 38.000 & $22.823,53$ & $7.204,47$ \\
Susu Fermentasi Kefir & 17 & 11.000 & 35.000 & $20.352,94$ & $5,379,70$ \\
Akupunktur \& & 17 & 16.000 & 39.000 & $23.411,76$ & $7.550,32$ \\
SusuFermentasi Kefir & & & & & \\
\hline
\end{tabular}

Berdasarkan tabel 4. menunjukkkan rata-rata subyek penelitian memiliki skor anti oksidan pada kelompok setelah terapi akupunktur 18.176,47 kelompok pemberian susu fermentasi kefir, 17.764,70, dan gabungan kelompok pemberian terapi akupunktur dan pemeberian susu fermentasi kefir 19.294,12

Tabel 4. Hasil pemeriksaan skor antioksidan sesudah dilakukan terapi akupunktur

\begin{tabular}{lccccc}
\hline & $\mathrm{N}$ & Min & Max & Mean & SD \\
\hline Akupunktur & 17 & 10.000 & 31.000 & $18.176,47$ & $6.204,47$ \\
Susu Fermentasi Kefir & 17 & 10.000 & 31.000 & $17.764,70$ & $5,379,70$ \\
Akupunktur \& Susu & 17 & 10.000 & 32.000 & $19.294,12$ & $6.687,34$ \\
Fementasi Kefir & & & & & \\
\hline
\end{tabular}

Hasil pemeriksaan antioksidan pada sebelum maupun sesudah dilakukan tindakan pada kelompok pemberian terapi akupunktur, kelompok pemberian susu fermentasi kefir maupun kelompok gabungan pemberian terapi akupunktur maupun susu fermentasi kefir ratarata kurang dari 25.000 dikatakan masih rendah. Hasil ini menunjukkan orang-orang yang mengkonsumsi "makanan dengan gizi buruk", konsumsi sayur dan buah yang rendah, jarang atau tidak mengkonsumsi suplemen, BMI > 28, tingkat stress tinggi, tinggi pemaparan sinar matahari dan polusi, dan perokok (termasuk perokok pasif). (Pharmanex BioPhotonic Scanner S3). Hal ini sejalan dengan yang dilakukan peneliti dari hasil penyebaran kuesioner (sehubungan dengan tidak ada pebedaan yang bermakna maka dilakukan penyebaran kuesioner yg berkaitan dengan hal-hal yang dapat mempengaruhi perubahan anti oksiden dalam tubuh manusia) bahwa $75 \%$ responden sering mengalami stress, $59 \%$ sering terpapar radikal bebas $3,9 \%$ yang sering minum suplemen dan hanya47 \% yang sering mengkonsumsi sayur dan buah. Apabila asupan gizi yang tidak cukup pada tubuh kita maka tubuh tidak dapat memberikan system pertahanan yang optimal, sehingga berakibat meningkatnya resiko penyakit-penyakit kronis.

Berdasarkan hasil pengujian normalitas dengan menggunakan shapirowilk diketahui bahwas susu fermentasi kefir (pretest) diperoleh $\mathrm{p}$ value $0,057>0,05$ sehingga dinyatakan data terdistribusi normal sedangkan susu fermentasi kefir (postest) diperoleh $\mathrm{p}$ value $0,145>0,05$ sehingga dinyatakan data terdistribusi normal, sehingga digunakan uji statistik parametrik yaitu paired sample t-test.

Hasil uji paired sample t-test diperoleh $\mathrm{p}$ value $0,001<0,05$ sehingga ada perbedaan yang signifikan antara sebelum dan sesudah perlakuan namun belum dapat menghambat proses penuaan dini. Karena yang seharusnya hasilnya pemeriksaan anti oksidan naik namun rata-rata mengalami penurunan. Dari hasil penelitian sebelumnya akupunktur yang 
dilaksanakan pada tikus atau mamalia dilakukan setiap dari dan selama 6 minggu, dari pemberian suplemen yang pernah dilakukan oleh peneliti untuk mendapatkan hasil yang sinigfikan setelah pemberian terusmenerus selama 12 minggu. Dari penelitian yang kita lakukan akupunktur hanya dilakukan selama 3 minggu dan 1 minggu dilakukan 3 kali, sedangkan pemberian susu kefir juga dilakukan selama 3 minggu; sehingga dalam penelitian ini belum menghasilkan perubahan antioksidan atau pemeriksaan karoteroid yang signifikan.

Penuaan merupakan suatu proses yang sangat kompleks dimana beberapa teori juga menjelaskan bahwa manifestasi seluler proses terjadinya penuaan juga dipengaruhi oleh faktor reactive oxygen species (ROS) yang dihasilkan dalam sel. ROS adalah produk sampingan dari respirasi aerobik yang terlibat dalam beberapa modifikasi reaksi seluler seperti paparan logam berat, radiasi pengion maupun zat oksidan. Secara normal, ROS dapat dihilangkan oleh adanya antioksidan endogen seperti superoksida dismutase (SOD), katalase (CAT), glutathione peroxidase (GPx) dan glutathione reduktase (GR). Akan tetapi oksidatif stres terjadi ketika keseimbangan antara oksidan dan antioksidan dalam tubuh berubah oleh karena peningkatan ROS dan penurunan antioksidan dari dalam tubuh maka akan dapat menyebabkan kerusakan sel dan juga akan mempengaruhi penuaan pada kulit Mekanisme ekstrak bahan alam dalam melindungi kulit terdapat beberapa cara seperti reduksi reaktivitas dari ROS, menghambat proses oksidasi, menyerap sinar UV, menekan aktivitas enzim, mereduksi pembentukan kerutan pada kulit serta melindungi kulit dari aging. (Jia et al., 2014; Kim et al., 2016).

Tabel 5. Hasil uji homogenitas

\begin{tabular}{ccccr}
\hline \multicolumn{5}{c}{ Test of Homogeneity of Variances } \\
\hline \multicolumn{4}{c}{ Penghambat Proses Penuaan Dini } \\
\hline Levene Statistic & df1 & \multicolumn{1}{c}{ df2 } & Sig. \\
\hline 204 & 2 & 48 & .816 \\
\hline
\end{tabular}

Hasil uji homogenitas diperoleh hasil $\mathrm{p}$ value $0,816>0,05$ sehingga data dinyatakan homogen sehingga dapat dilanjutkan dengan uji ANOVA.

Tabel 6. Hasil uji Multiple Comparasions antar kelompok

\begin{tabular}{|c|c|c|c|c|c|c|}
\hline $\begin{array}{l}\text { Depender } \\
\text { Scheffe }\end{array}$ & Variable: peng & $\begin{array}{l}\text { Multiple } \\
\text { nbat proses pen }\end{array}$ & $\begin{array}{l}\text { lparisons } \\
\text { n dini }\end{array}$ & & & \\
\hline (I) Kelompok & (J) Kelompok & Mean Difference & Std. Error & Sig. & $95 \%$ Confid & ence Interval \\
\hline & & $(\mathrm{I}-\mathrm{J})$ & & & Lower Bound & Upper Bound \\
\hline & Kefir & 411.76471 & 2088.16625 & .981 & -4863.2651 & 5686.7945 \\
\hline Akupuntur & Akupuntur + Kefir & -1117.64706 & 2088.16625 & .867 & -6392.6769 & 4157.3827 \\
\hline$Y f_{0}$ & Akupuntur & -411.76471 & 2088.16625 & .981 & -5686.7945 & 4863.2651 \\
\hline Kefir & Akupuntur + Kefir & -1529.41176 & 2088.16625 & .766 & -6804.4416 & 3745.6180 \\
\hline 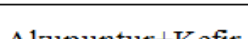 & Akupuntur & 1117.64706 & 2088.16625 & .867 & -4157.3827 & 6392.6769 \\
\hline Akupuntur+Kenl & Kefir & 1529.41176 & 2088.16625 & .766 & -3745.6180 & 6804.4416 \\
\hline
\end{tabular}

Radikal bebas adalah suatu molekul, atom atau beberapa atom yang mempunyai satu atau lebih elektron tidak berpasangan pada orbit luarnya sehingga bersifat sangat reaktif yang bersumber dari polutan, sinar $\mathrm{x}$, sinar ultraviolet, asap rokok, stress, sakit, olah raga berlebihan dan makanan sumber lipid. Radikal bebas dalam tubuh dapat berasal dari dalam (endogen) atau dari luar tubuh (eksogen). Secara endogen, radikal bebas dapat berasal dari makanan sumber lipid yang dapat membentuk peroksidasi lipid di dalam tubuh, selain itu, radikal radikal endogen juga bisa disebabkan oleh kondisi stress, sakit dan olah raga yang berlebihan. Secara eksogen, radikal bebas bersumber dari polutan, sinar $\mathrm{X}$, asap rokok, radiasi dan lain-lain. Secara alami tubuh dapat menghasilkan antioksidan, yang disebut sebagai antioksidan endogen seperti superoksida dismutase (SOD), katalase (CAT), glutation peroksidase (GPx), glutation reduktase (GR) dan seruloplasmin. Apabila jumlah radikal bebas lebih tinggi dibandingkan antioksidan endogen dapat menimbulkan stress oksidatif dalam tubuh.

Stress oksidatif dalam tubuh menimbulkan kerusakan pada sel. Stress oksidatif dalam tubuh dapat diukur dengan menggunakan salah 
satu parameternya yaitu kadar MDA plasma. Semakin tinggi stress oksidatif yang terjadi dalam tubuh maka semakin tinggi kadar MDA plasma. Stress oksidatif dalam tubuh dapat diredam oleh antioksidan eksogen baik yang alami berasal dari bahan pangan ataupun yang berasal dari suplemen seperti suplemen vitamin $\mathrm{C}$, vitamin $\mathrm{E}$ dan multi vitaminmineral, sehingga dapat menurunkan kadar MDA plasma. MDA adalah senyawa aldehida yang merupakan produk akhir peroksida lipid di dalam tubuh. Senyawa ini memiliki tiga rantai karbon, dengan rumus molekul $\mathrm{C} 3 \mathrm{H} 4 \mathrm{O} 2$. MDA juga merupakan produk dekomposisi dari asam amino, karbohidrat kompleks, pentose dan heksosa. Selain itu,
MDA juga merupakan produk yang dihasilkan oleh radikal bebas melalui reaksi ionisasi dalam tubuh dan produk sampah biosintesis prostaglandin yang merupakan produk akhir oksidasi lipid membran. Menurut Helliwell dan Gutteridge (1999), MDA merupakan produk oksidasi asam lemak tidak jenuh oleh radikal bebas. Di samping itu, MDA juga merupakan metabolit komponen sel yang dihasilkan oleh radikal bebas. Konsentrasi MDA yang tinggi menunjukkan adanya proses oksidasi dalam membran sel. Status antioksidan yang tinggi biasanya diikuti oleh penurunan kadar MDA.

Tabel 7. Hasil Uji Anova

\begin{tabular}{|c|c|c|c|c|c|}
\hline \multicolumn{6}{|c|}{ ANOVA } \\
\hline & Sum of Squares & $\mathrm{df}$ & Mean Square & $\mathrm{F}$ & Sig. \\
\hline Between Groups & 21294117.647 & 2 & 10647058.824 & .287 & .752 \\
\hline Within Groups & 1779058823.529 & 48 & 37063725.490 & & \\
\hline Total & 1800352941.176 & 50 & & & \\
\hline
\end{tabular}

Uji Anova digunakan untuk mengetahui perbedaan antar kelompok perlakuan. Hasil uji anova diperoleh $\mathrm{p}$ value $0,752>0,05$ sehingga dinyatakan tidak ada perbedaan antara ketiga perlakuan yaitu pemberian terapi akupuntur; susu fermentasi kefir maupun kombinasi pemberian terapi akupuntur dan susu fermentasi kefir untuk menghambat proses penuaan dini di Kota Surakarta.

Hasil uji Anova menunjukkan bahwa tidak adanya perbedaan antara ketiga perlakuan yaitu pemberian terapi akupuntur; susu fermentasi kefir maupun kombinasi pemberian terapi akupuntur dan susu fermentasi kefir untuk menghambat proses penuaan dini di Kota Surakarta. Hal ini dapat disebabkan karena adanya faktor eksternal dan internal yang mempengaruhi subyek penelitian yang bersifat heterogen.

Subyek penelitian adalah terbanyak adalah para mahasiswi di Perguruan Tinggi Wilayah Solo yang berusia 20 - 30 tahun; yang merupakan salah satu kelompok yang rentan terkena berbagai radikal bebas yang berasal dari aktivitas metabolik regular, aktivitas fisik, gaya hidup maupun diet. Kualitas dan kuantitas aktivitas yang dilakukan subyek penelitian yang beragam antara lain kegiatan perkuliahan yang dimulai pada sore hari sampai malam, tidur yang terlalu larut menuntut tubuh untuk lebih banyak beraktivitas (stress), Selain itu, polutan yang berasal dari asap kendaraan bermotor, rokok (pasif) dan lainnya. Tidak hanya itu, makanan juga dapat menjadi penyebab meningkatnya radikal bebas dalam tubuh. Para mahasiswi sangat gemar mengonsumsi makanan gorengan seperti tempe, bakwan, molen, pisang, tahu, combro, ubi dan kentang karena harganya yang murah, ataupun pecel ayam dan pecel lele serta makanan fast food baik gorengan maupun pecel ayam ataupun lele yang dijual, digoreng menggunakan minyak yang berwarna keruh hampir berwarna hitam menandakan minyak telah digunakan berulang-ulang oleh penjual. Minyak tersebut memiliki peroksida lipid yang tinggi dan mungkin dapat menjadi penyebab meningkatnya radikal bebas dalam tubuh. Menurut Papalia dan Olds (1988), kondisi kejiwaan dan gaya hidup adalah penyebab paling umum dari terjadinya masalah-masalah fisik. Ruang lingkup masalah tersebut adalah kebiasaan makan yang salah (eating disorders).

Konsumsi antioksidan dalam jumlah memadai dilaporkan dapat menurunkan kejadian penyakit yang ditimbulkan oleh 
radikal bebas seperti penyakit degeneratif, kanker. Konsumsi makanan yang mengandung antioksidan dapat meningkatkan status imunologis dan menghambat timbulnya penyakit degeneratif karena penuaan. Oleh sebab itu, kecukupan asupan antioksidan secara optimal diperlukan pada semua kelompok umur (Winarsi 2011). Defisiensi antioksidan berupa vitamin $\mathrm{C}$, vitamin $\mathrm{E}$, Seng, Se, dan Tembaga dalam derajat ringan ataupu berat, sangat berpengaruh terhadap kadar radikal bebas dalam tubuh (Meydani et al 1995). Kerusakan oksidatif terjadi sebagai akibat dari rendahnya antioksidan dalam tubuh sehingga tidak dapat mengimbangi reaktivitas senyawa oksidan.

Kefir sebagai minuman probiotik atau suplemen pangan yang biasa dikonsumsi karena diketahui dapat bermanfaat menurunkan kolesterol karena aktivitas dari mikroorganisme bakteri dan beberapa jenis khamir yaitu Lactobacillus parakefir menfermentasi asam laktat dari laktosa. $L$. kefiranofaciens sebagai pembentuk lendir (matriks butiran kefir) dan Leuconostoc $s p$ membentuk diasetil dari sitrat serta Candida kefir pembentuk etanol dan karbon dioksida dari laktosa. Aktifitas fermentasi bakteri asam laktat pada kefir menghasilkan senyawa kompetitif yang dapat mencegah HMG CoA agar tidak berikatan dengan HMG CoA reduktase; hal ini yang menyebabkan terhambatnya sintesis kolesterol (Pratama, 2012).

Hasil penelitian Jianchun Yu et al (2005) menunjukkan bahwa akupuntur dapat mencegah ekspresi gen penginduksi aging sehingga di masa yang akan datang dapat digunakan sebagai proses dan terapi klinis anti aging.

\section{KESIMPULAN}

a. Karakteristik responden meliputi umur dan jenis kelamin.

b. Jenis kelamin responden yaitu 84,31\% perempuan, dan $15 \%$ laki-laki.

c. Usia responden dominan adalah 20 - 30 tahun yaitu 90,2 \% dan pemeriksaan anti oksidan ternyata tidak terpengaruh dengan usia.

d. Skor anti oksidan pada kelompok sebelum terapi akupunktur sebesar 22.823,53 dan kelompok pemberian susu fermentasi kefir sebesar 20.352,94, dan gabungan kelompok pemberian terapi akupunktur dan pemberian susu fermentasi kefir sebesar 23.411,76

e. Skor anti oksidan pada kelompok setelah terapi akupunktur 18.176,47 kelompok pemberian susu fermentasi kefir, 17.764,70, dan gabungan kelompok pemberian terapi akupunktur dan pemeberian susu fermentasi kefir 19.294,12

f. Tidak ada perbedaan antara ketiga perlakuan yaitu pemberian terapi akupuntur; susu fermentasi kefir maupun kombinasi pemberian terapi akupuntur dan susu fermentasi kefir untuk menghambat proses penuaan dini di Kota Surakarta.

\section{SARAN}

Perlu dilakukan penelitian lebih lanjut tentang variabel titik akupunktur yang lain dan homogenitas perlakuan seperti faktor usia, pemberian suplemen kefir dengan dosis yang sama dalam waktu yang lebih terkontrol terhadap pengaruh eksternal lainnya yaitu aktivitas dan asupan gizi yang relatif sama sehingga dapat dieliminir faktor perancu penelitian.

\section{UCAPAN TERIMA KASIH}

Ucapan terima kasih kepada Poltekes Kemenkes Surakarta yang telah memfasilitasi pendanaan melalui Program Penelitian Hibah Bersaing Tahun anggaran 2019.

\section{REFERENSI}

Ding, X., Jianchun Y., Tao Y., Yu F., \& Jingxian H., 2006. Acupuncture regulates the aging-related changes in gene profile expression of the hippocampus in senescence-accelerated mouse (SAMP10). Neuroscience Letters 399 (2016) 11-16. doi:10.1016/j.neulet.2016.01.067. China : Tianjin.

Hidayat, Nur, Padag, Masdiana C., Suhartini, Sri.2006. Mikrobiologi Industri Yogyakarta Penerbit ANDI.

Jia, N., Li, T., Diao, X., Kong, B., 2014. Protective effects of black currant (Ribes nigrum L.) extract on hydrogen peroxide-induced damage in lung fibroblast MRC-5 cells in relation to the antioxidant activity. J. Funct. Foods 11, 142-151. 
Jianchun Yu, Tao Yu, Jingxian Han, 2005.

Aging-Related Changes in The Transcriptional Profile of Cerebrum in Senescence-Acclerated Mouse (SAMP 10) is Remarkably Retarded by Acupuncture. Acupuncture \& Electro-Therapeutics Res. Int. J. Vol, pp.27-42

Kim, D.-B., Shin, G.-H., Kim, J.-M., Kim, Y.H., Lee, J.- H., Lee, J.S., Song, H.-J., Choe, S.Y., Park, I.-J., Cho, J.-H., Lee, O.H., 2016. Antioxidant and anti-ageing activities of citrus-based juice mixture. Food Chem. 194, 920-927.

Maria, D., 2007. Merawat kulit dan Wajah. Jakarta : PT Kawan Pustaka

Meydani SN et al. 1995. Antioxidant and immune response in Aged persons: Overview of present evidence. The American Journal of Clinical Nutrition. 62: 1462S-1476S.

Noor Mindhawati. (2013). Menghambat Proses Penuaan. Yogyakarta : Rapha Publishing.

Papalia DE, Olds Sw. 1988. Human Development. Edisi ke-2. New York: Mc Grow Hill Book Company.

Pratama, Sandy Eka, 2012. Pengaruh Pemberian Kefir Susu Spai Terhadap Kadar Kolesterol LDL Tikus Jantan Sprague Dawley Hiperkolesterolemia. Artikel Penelitian. Semarang: Program Studi Ilmu Gizi Fakultas Kedokteran Universitas Diponegoro Semarang.

Winarsi Hery. 2011. Antioksidan Alami dan Radikal Bebas. Kanisius, Yogyakarta.

Xuemin, S., 2007. Acupuncture and Moxibustion. Beijing: Higher Education Press. 